\title{
EFISIENSI EKONOMI PENGGUNAAN FAKTOR PRODUKSI USAHATANI JAGUNG MANIS DI KECAMATAN KUMPEH ULU KABUPATEN MUARO JAMBI
}

\author{
Gerhayana $^{1}$, Dompak Napitupulu ${ }^{2}$, Saidin Nainggolan ${ }^{3}$ \\ ${ }^{1)}$ Alumni Jurusan Agribisnis Fakultas Pertanian Universitas Jambi \\ ${ }^{2)}$ Staf Pengajar Jurusan Agribisnis Fakultas Pertanian Universitas Jambi \\ Email:anasitorus163@yahoo.co.id
}

\begin{abstract}
ABSTRAK
Penelitian ini bertujuan untuk mengetahui pengaruh faktor produksi terhadap produksi jagung manis dan mengetahui tingkat efisiensi penggunaan faktor produksi pada usahatani jagung manis di Kecamatan Kumpeh Ulu Kabupaten Muaro Jambi. Metode penelitian yang digunakan adalah obsevasi dan wawancara, dengan jumlah sampel 64 responden yang diambil secara acak sederhana (Simple Random Sampling). Hasil penelitian menunjukan penggunaan faktor-faktor produksi jagung dinyatakan dalam model fungsi produksi Cobb-Douglas, sebagai berikut: $Y=2,305 \cdot X_{1}^{0,124} \cdot X_{2}^{0,751}$. $X_{3}^{0,048} \cdot X_{4}^{0,072}$. Secara individual, faktor produksi tenaga kerja dan pupuk kandang berpengaruh nyata terhadap produksi jagung sedangkan faktor produksi benih dan pupuk urea tidak berpengaruh nyata terhadap produksi jagung. Analisis usahatani jagung luas lahan sebesar $1.3828 \mathrm{Ha}$, biaya usahatani jagung Rp. 2723812.598/Ha, penerimaan usahatani Rp.13508593.75/Ha, dan pendapatan usahatani sebesar Rp. 19121675.47/Ha. Berdasarkan hasil penelitian tersebut, kombinasi penggunaan faktorfaktor produksi pada usahatani jagung belum mencapai efisiensi ekonomi tertinggi. Maka untuk meningkatkan efisiensi ekonomi pada usahatani jagung, petani perlu mengoptimalkan penggunaan tenaga kerja dan pupuk kandang.
\end{abstract}

Kata Kunci: Usahatani Jagung Manis, Cobb-Douglas, Efisiensi Ekonomi.

\section{ABSTRACT}

The purposes of this study are to detemine the influence of factor on to the production of sweet corn and to determine the level of production factors efficiency on sweet corn farm in the Kumpeh Ulu Muaro Jambi Regency. Data were collected in observation and interview method. The number of farmer sample was 64 respondents which were drawn by using simple random sampling. The result of research showed that the use of corn production factors expressed in the Cobb-Douglas production function model could be formulated as : $Y=2,305 X_{1}^{0,124} \cdot X_{2}^{0,751} \cdot X_{3}^{0,048} \cdot X_{4}^{0,072}$. Individually, the labor and manure factors affected significantly to the corn productivity, but the seeds and $N$-fertilizer factors did not. The analyisis on corn farming indicated that average farm area cultivated was 1.3828 $\mathrm{Ha}$, average cost was Rp.2,723,812.59/Ha, revenue was Rp.13,508,593.75/Ha, and farm income was Rp.19,121,675.47/Ha. Considering the result of research, the combined use of production factors in corn farming had not reached yet the highest economic efficiency. From the result of research, it was reccommended to improve the economic efficiency in corn farming such as by optimizing the use of labor and manure.

Keywords: Sweet Corn Farm, Production Factors, Cobb-Douglas, Economic Efficiency. 


\section{PENDAHULUAN}

Pembangunan pertanian selalu diarahkan untuk mewujudkan pertanian yang tangguh, maju dan efisien yang dicirikan oleh kemampuannya dalam mensejahterakan petani. Kemampuan tersebut dapat dicapai melalui peningkatan kualitas dan produksi serta keanekaragaman hasil pertanian yang memenuhi kebutuhan pangan dan gizi, memperluas kesempatan kerja dan mengembangkan ekonomi pedesaan yang mampu memanfaatkan peluang pasar. Sesuai dengan arah pembangunan pertanian dalam arti luas dan dalam rangka memanfaatkan peluang pasar dan keunggulan yang ada, produksi pertanian tanaman pangan terus dikembangkan agar mampu memenuhi kebutuhan pasar dalam negri dan bahkan permintaan luar negri. Untuk itu perlu adanya perhatian khusus terhadap komoditi-komditi apa saja yang memiliki prospek untuk dikembangkan disetiap daerah.

Provinsi Jambi merupakan salah satu daerah penghasil jagung di Indonesia yang terus berkembang hingga saat ini. Perkembangan, Luas Panen, Produksi, dan Rata-rata Produksi jagung di Provinsi Jambi Tahun 2003- 2011. Peningkatan produktivitas tanaman jagung dari tahun 2003 sampai 2011. Walaupun pada tahun 2008 luas panen dan produksi tanaman jagung mengalami penurunan luas panen. Pada tahun 2003 produktivitas tanaman jagung hanya 3.02 ton/ ha dan pada tahun 2011 produktivitas tanaman jagung meningkat menjadi 3.63 ton/ ha. Kabupaten Muaro Jambi merupakan penghasil jagung terbesar di Provinsi Jambi, hal ini sesuai dengan hasil survey pendahuluan (Januari, 2013), ternyata jagung yang terdapat di Kota Jambi berasal dari daerah Kabupaten Muaro Jambi, daerah ini lah yang sangat potensial menjadi sentra usahatani jagung manis, wilayah yang cocok untuk dijadikan sentra usahatani jagung manis di Kabupaten Muaro Jambi yaitu terdapat di daerah Kecamatan Kumpeh Ulu, karena lahan yang digunakan dalam usahatani jagung manis relatif sempit. Menurut Kepala Balai Penyuluh Pertanian Kecamatan Kumpeh Ulu, petani jagung manis ini merupakan petani yang mampu berdiri sendiri, maksudnya yaitu petani yang tidak lagi mendapatkan bantuan benih BLBU (Bantuan Langsung Benih Unggul) dari Pemerintah daerah Kabupaten Muaro Jambi.

Untuk meningkatkan produktivitas jagung manis, petani di hadapkan pada suatu masalah dalam penggunaan faktor produksi dalam usahatani, yaitu luas lahan, tenaga kerja dan modal yang tepat. Dalam menghadapi masalah tersebut penggunaan luas lahan usahatani jagung manis yang semakin berkurang akibat konversi lahan pertanian menjadi areal pemukiman, maka hal ini berdampak bagi produksi usahatani jagung manis. Berdasarkan permasalahan diatas, maka perlu untuk dilakukan penelitian lebih lanjut mengenai tingkat efisiensi dari penggunaan faktor produksi terutama bagi peningkatan produksi yang nantinya akan berpengaruh pada peningkatan produktivitas. Dimana tujuan dari penelitian ini adalah Untuk menganalisis pengaruh faktor produksi terhadap produksi usahatani jagung manis di Kecamatan Kumpeh Ulu Kabupaten Muaro Jambi. Dan Untuk mengetahui efisiensi ekonomi penggunaan faktor produksi usahatani jagung manis di Kecamatan Kumpeh Ulu Kabupaten Muaro Jambi. Berdasarkan landasan teori maka dapat ditarik hipotesis yaitu Untuk menganalisis pengaruh faktor produksi terhadap produksi usahatani jagung manis di Kecamatan Kumpeh Ulu Kabupaten Muaro Jambi. Dan Untuk mengetahui efisiensi ekonomi penggunaan faktor produksi usahatani jagung manis di Kecamatan Kumpeh Ulu Kabupaten Muaro Jambi. 


\section{METODOLOGI PENELITIAN}

Penelitian ini dilaksanakan di Kecamatan Kumpeh Ulu Kabupaten Muaro Jambi. Kecamatan Kumpeh Ulu terdiri dari 17 desa yang mengusahakan komoditi jagung, seluruh desa di Kecamatan Kumpeh Ulu telah mengusahakan usahatani jagung manis. Dari 17 desa dipilih 2 desa adapun desa yang terpilih adalah Desa Kasang Lopak Alai dan Desa Lopak Alai. Dalam melakukan penelitian di daerah ini dipilih 2 Desa secara sengaja (Purposive) sebagai sampel dengan pertimbangan bahwa kedua desa tersebut telah menggunakan faktor produksi berupa lahan, tenaga kerja, pupuk, pestisida dan benih jagung manis dalam upaya meningkatkan produksi dan merupakan daerah sentra dan daerah percontohan usahatani jagung manis di Kecamatan Kumpeh Ulu. Metode pengambilan sampel yang akan digunakan dengan acak sederhana (Simple Random Sampling).Untuk menentukan jumlah sampel dari populasi menurut Slovin (1964) dalam Nazir (2005) dapat mengunakan rumus:

Dimana:

$$
n=\frac{N}{1+N \cdot d^{2}}
$$

$$
\begin{aligned}
& n=\text { jumlah sampel } \\
& N=\text { jumlah populasi } \\
& d=\text { tingkat presisi }(10 \%)
\end{aligned}
$$

Berdasarkan rumus diatas maka jumlah sampel dalam penelitian ini adalah 64 responden yang terdiri dari 50 responden dari Desa Kasang Lopak Alai dan 14 sampel dari Desa Lopak Alai. Selanjutnya analisis pendapatan usahatani dalam penelitian ini digunakan dengan pendekatan rumus:

$$
\begin{aligned}
\mathrm{Pd} & =\mathrm{TR}-\mathrm{TC} \\
& =\mathrm{Py} \times \mathrm{Y}-\mathrm{BM}
\end{aligned}
$$

Dimana:

$\mathrm{Pd}=$ Pendapatan usahatani jagung manis $(\mathrm{Rp} / \mathrm{Ha})$

$\mathrm{TR}$ = Penerimaan total usahatani jagung manis $(\mathrm{Rp} / \mathrm{Ha})$

$\mathrm{TC}=$ Biaya total usahatani jagung manis $(\mathrm{Rp} / \mathrm{Ha})$

Py = Harga jagung per $\mathrm{kg}(\mathrm{Rp})$

$\mathrm{Y}=$ Produksi jagung $(\mathrm{kg})$, dan

$\mathrm{BM}$ = Biaya mengusahakan usahatani jagung manis $(\mathrm{kg} / \mathrm{Ha})$

Analisis pengaruh penggunaan faktor produksi usahatani jagung manis menggunakan model modifikasi fungsi produksi Cobb-Douglas dengan rumus:

$$
\mathrm{Y}=\mathrm{ax}_{1}{ }^{\mathrm{b} 1} \cdot \mathrm{X}_{2}^{\mathrm{b} 2} \cdot \mathrm{X}_{3}^{\mathrm{b} 3} \cdot \mathrm{X}_{4}^{\mathrm{b} 4}
$$

Dimana:

$$
\begin{aligned}
Y & =\text { Produksi Jagung } \\
X_{1} & =\text { Tenaga Kerja } \\
X_{2} & =\text { Benih } \\
X_{3} & =\text { Pupuk Kandang } \\
X_{4} & =\text { Pupuk Urea } \\
a & =\text { Konstanta } \\
b_{1}-b_{4} & =\text { Koefisien Regresi }
\end{aligned}
$$


Selanjutnya Pengaruh masing-masing faktor produksi terhadap hasil produksi jagung digunakan Uji T dan untuk mengetahui faktor produksi mana yang paling berpengaruh diantara faktor produksi yang lain digunakan uji standard koefisien yang regresi dengan rumus:

$$
\mathrm{T}_{\text {hit }}=\frac{\mathrm{bi}}{\mathrm{Sbi}}
$$

Dimana :

$$
\begin{aligned}
& t_{\text {hit }}=\text { Nilai t hitung } \\
& b_{i}=\text { Koefisien regresi perkiraan ke- } b_{i} \\
& S b_{i}=\text { Standar eror perkiraan ke- } b_{i} \\
& i \quad=1,2,3 \ldots
\end{aligned}
$$

Nilai $R^{2}$ berkisar antara 0 dan 1 . Nilai $R^{2}$ yang mendekati 1 menunjukan bahwa model ekonometrika yang digunakan semakin baik. Berarti semakin baik besar nilai $\mathrm{R}^{2}$ maka semakin besar pula kemampuan variabel $\mathrm{X}$ untuk menjelaskan variabel $\mathrm{Y}$. Setelah nilai dari koefisien determinasi $R^{2}$ di dapat, maka dihitung nilai uji $F$ dengan rumus:

Dimana:

$$
\mathrm{F}_{\text {hit }}=\frac{\mathrm{R}^{2} /(\mathrm{k}-1)}{\left(1-R^{2}\right) /(n-k)}
$$

$\mathrm{R}^{2}=$ Koefisien determinasi

$\mathrm{K}=$ Jumlah variabel independent atau derajat bebas $(\mathrm{db})$ regresi

$\mathrm{n}=$ Jumlah sampel penelitian

$\alpha=$ Taraf keyakinan penelitian $90 \%$ atau $\alpha=10 \%$

Pengujian tingkat efisiensi penggunaan faktor produksi dilakukan dengan membandingkan nilai produk marjinal (NPM) dengan harga faktor produksi (Hx) yang merupakan biaya korbanan per unit. Menurut soekartawi (1994), pengujian tingkat efisiensi ekonomis penggunaan faktor produksi dilakukan dengan membandingkan nilai produk marginal (NPM) dengan harga faktor produksi $(\mathrm{Hx})$, yakni dengan kaidah sebagai berikut :

$$
\frac{N P M x 1}{P x 1}=\frac{N P M x 2}{P x 2}=\frac{N P M x 3}{P x 3}=\frac{N P M x 4}{P x 4}=1
$$

$$
\begin{array}{ll}
\frac{N P M x i}{H x i}<1 & \text { artinya penggunaan faktor produksi ke-i tidak efisien, untuk mencapai } \\
& \text { efisiensi maka faktor produksi perlu dikurangi } \\
\frac{N P M x i}{H x i}=1 & \text { artinya berarti penggunaan input sudah efisien } \\
\frac{N P M x i}{H x i}>1 & \text { artinya penggunaan faktor produksi ke-i belum efisien, untuk mencapai } \\
& \text { efisien maka faktor produksi perlu ditambah }
\end{array}
$$




\section{HASIL DAN PEMBAHASAN}

\section{Identitas Petani Sampel}

Umur petani mempunyai pengaruh terhadap kemampuan fisik petani dalam mengelola usahatani maupun usaha lain diluar usahatani. Semakin tinggi umur petani kemampuan fisik petani untuk bekerja pada lahan usahatani relative menurun. Pada umur 2040 kekuatan fisik cenderung stabil, namun dari umur 41-60 kemampuan fisik petani cenderung menurun. Hal ini tentunya perlu di perhatikan karena pada umumnya petani hanya mengandalkan kekuatan fisik atau tenaga dalam mencari nafkah. Untuk lebih jelasnya penyebaran umur petani dapat dilihat sebagai berikut.

Tabel 1. Distribusi frekuensi petani sampel berdasarkan umurdi Kecamatan Kumpeh Ulu Tahun 2013.

\begin{tabular}{ccc}
\hline Selang Kelas Umur (Tahun) & Frekuensi (Orang) & Persentase (\%) \\
\hline $25-29$ & 9 & 14,06 \\
$30-34$ & 7 & 10,94 \\
$35-39$ & 15 & 23,44 \\
$40-44$ & 8 & 12,5 \\
$45-49$ & 9 & 14,06 \\
$50-54$ & 8 & 12,5 \\
$55-59$ & 5 & 7,81 \\
$60-64$ & 3 & 4,69 \\
\hline Jumlah & 64 & $100 \%$ \\
\hline
\end{tabular}

\section{Hubungan Faktor-faktor Produksi dengan Produksi Jagung Manis}

Hubungan antara faktor produksi dengan produksi dalam usahatani jagung manis ditunjukan dengan modifikasi fungsi produksi Cobb-Douglas . Faktor produksi yang dimasukkan kedalam persamaan adalah faktor produksi yang berupa tenaga kerja, benih, pupuk kandang, dan pupuk urea.

Model modifikasi fungsi Cobb-Douglas adalah regresi non linear berganda sehingga untuk melakukan analisis regresi linear berganda harus diubah kedalam bentuk persamaan linear. Untuk itu persamaan yang ada dilogaritmakan menjadi modrl regresi linear berganda. Dalam model Cobb-Douglas ini, uji yang dilakukan adalah uji F, uji keberartian koefisien regresi dengan uji t. Adapun model fungsi produksi jagung manis adalah sebagai berikut:

$\log Y=\log 2,305+0,124 \log X_{1}+0,751 \log X_{2}+0,048 \log X_{3}+0,072 \log X_{4}$

Dimana:

$Y=$ Produksi jagung $(\mathrm{kg})$,

$\mathrm{X}_{1}=$ Tenaga kerja (HOK),

$X_{2}=\operatorname{Benih}(\mathrm{kg})$,

$\mathrm{X}_{3}=$ Pupuk Kandang $(\mathrm{kg})$,

$\mathrm{X}_{4}=$ Pupuk Urea $(\mathrm{kg})$.

Uji Determinasi. Hasil analisis menunjukan nilai adjusted $\mathrm{R}^{2}$ sebesar 0,893 . Ini berarti bahwa variasi produksi jagung $89,3 \%$ di pengaruhi oleh variabel tenaga kerja, benih, pupuk kandang, pupuk urea, sedangkan $10,7 \%$ dijelaskan oleh faktor lain yang tidak termasuk kedalam model analisis. 
Pengaruh faktor-faktor produksi terhadap produksi jgung manis. Pengaruh penggunaan faktor produksi berupa tenaga kerja, benih, pupuk kandang dan pupuk urea secara bersama-sama terhadap produksi jagung manis dapat diketahui dengan melakukan uji $\mathrm{F}$ dan uji t terhadp persamaan model fungsi produksi yang telah diperoleh. Hasil uji $F$ menunjukan $F$ sebesar 117,692 lebih besar dari $F$ tabel (2,374). Hal ini menunjukan bahwa faktor produksi yang berupa tenaga kerja, benih, pupuk kandang, pupuk urea secara bersama-sama berpengaruh terhadap produksi jagung manis di Kecamatan Kumpeh Ulu Kabupaten Muaro Jambi.

Sementara itu uji t untuk mengetahui pengaruh penggunaan faktor-faktor produksi secara individu atau masing-masing terhadap produksi jagung manis pada taraf $95 \%$ atau nilai signifikansi adalah 0,05. Hasil analisis menunjukan bahwa tenaga kerja berpengaruh nyata terhadap produksi jagung dan nilai elastisitas produksi tenaga kerja sebesar 0,124 , yang artinya setiap penambahan tenaga kerja sebesar $10 \%$, maka akan meningkatkan produksi jagung sebesar $1,24 \%$. Benih tidak berpengaruh nyata dengan nilai koefisien regresi sebesar $0,751 \%$. Hal ini berarti setiap penambahan $10 \%$ maka akan mengakibatkan peningkatan produksi jagung sebesar $7,51 \%$. Faktor produksi pupuk kandang sebesar 0,048 yang artinya setiap penambahan $10 \%$ pupuk kandang akan mengakibatkan penambahan produksi jagung sebesar $0,48 \%$. Faktor pupuk urea sebesar 0,072 yang artinya penambahan pupuk urea sebesar $10 \%$ akan mengakibatkan terjadi peningkatan produksi sebesar $0,72 \%$.

\section{Analisis Fungsi Produksi dan Efisiensi Ekonomis Penggunaan Faktor Produksi pada Usahatani Jagung Manis}

Hasil analisis penggunaan faktor produksi dilakukan melalui pendekatan fungsi Coob-Douglass, dimana variabel dependen $(\mathrm{Y})$ adalah produksi dan variabel independen $(\mathrm{X})$ adalah faktor produksi yang digunakan pada usahatani jagung. Variabel $\mathrm{X}$ terdiri tenaga kerja $\left(X_{1}\right)$, benih $\left(X_{2}\right)$, pupuk kandang $\left(X_{3}\right)$, dan pupuk urea $\left(X_{4}\right)$. Untuk mengetahui nilai estimasi parameter fungsi produksi jagung di daerah penelitian tahun 2013 dapat dilihat pada tabel dibawah ini.

Tabel 2. Analisis Regresi Penggunaan Faktor Produksi Jagung Manis Daerah Penelitian Musim Tanam 2013

\begin{tabular}{lccc}
\hline \multicolumn{1}{c}{ Variabel Independen } & Koef. Regresi & $T_{\text {-hitung }}$ & Sig \\
\hline Log Tenaga Kerja & 0,124 & 1,655 & 0,103 \\
Log Benih & 0.751 & 8,619 & 0,000 \\
Log Pupuk Kandang & 0,048 & 0,403 & 0,688 \\
Log Pupuk Urea & 0,072 & 1,059 & 0,294 \\
\hline Jumlah Koef. Regresi & 0,995 & & \\
Konstan & 2,305 & & \\
Koef. Determinasi $\left(\mathrm{R}^{2}\right)$ & 0,889 & & \\
\hline
\end{tabular}

Dari Tabel 2 diperoleh koefisien determinasi $\left(R^{2}\right)$ sebesar 0,889 ini berarti 88,9\% variasi produksi usahatani jagung manis dapat dijelaskan oleh tenaga kerja, benih, pupuk kandang, dan pupuk urea. Sedangkan sisanya $12 \%$ dijelaskan oleh faktor lain yang tidak termasuk kedalam model analisis. Selanjutnya dari analisis sidik ragam tersebut diperoleh Fhitung sebesar 117,692 dan $\mathrm{F}_{\text {-tabel }}$ pada taraf $95 \%(0,05)$ sebesar 2,374. Dengan demikian $\mathrm{F}_{\text {-hitung }}$ $>\mathrm{F}_{\text {-tabel }}$ yang berarti secara bersama-sama variabel bebas (xi) yaitu tenaga kerja, benih, pupuk kandang, pupuk urea mempengaruhi produksi jagung manis. 
Kemudian dilanjutkan dengan uji t untuk melihat pengaruh masing-masing variabel bebas terhadap produksi jagung manis. Dari lampiran 19 terlihat bahwa Koefisien regresi tenaga kerja adalah 0,124 yang berarti setiap penambahan tenaga kerja sebesar $10 \%$, maka akan meningkatkan produksi jagung sebesar $1,24 \%$. Variabel tenaga kerja berpengaruh nyata terhadap peningkatan produksi jagung manis. Hal ini ditunjukan oleh nilai t-hit $<\mathrm{t}$-tab yaitu 1,655 lebih kecil dari 2,300 maka keputusannya tolak $\mathrm{H} 1$ terima HO berarti penambahan tenaga kerja tidak berpengaruh nyata terhadap peningkatan produksi jagung manis pada tingkat keyakinan $99,9 \%$.

Koefisien regresi benih adalah 0,751 yang berarti setiap penambahan benih sebesar $10 \%$ maka akan mengakibatkan peningkatan produksi jagung sebesar $7,51 \%$. Variabel benih tidak berpengaruh nyata terhadap peningkatan produksi jagung manis. Hal ini ditunjukan oleh nilai t-hit > t-tab (95\%) yaitu 8,619 lebih besar dari 2,300 maka keputusannya terima $\mathrm{H} 1$ tolak HO berarti penambahan benih berpengaruh nyata terhadap peningkatan produksi jagung manis.

Koefisien regresi pupuk kandang adalah 0,048 yang berarti setiap penambahan $10 \%$ pupuk kandang akan mengakibatkan penambahan produksi jagung sebesar $0,48 \%$. Variabel pupuk kandang tidak berpengaruh nyata terhadap peningkatan produksi jagung manis. Hal ini ditunjukan oleh nilai t-hit < yaitu 0,403, lebih kecil dari 2,300 maka keputusannya tolak H1 terima $\mathrm{HO}$ berarti bahwa penambahan pupuk kandang tidak berpengaruh nyata terhadap peningkatan produksi jagung manis pada tingkat keyakinan 99,7\%.

Koefisien regresi pupuk urea adalah 0,072 yang berarti setiap penambahan pupuk urea sebesar $10 \%$ akan mengakibatkan terjadi peningkatan produksi sebesar $0,72 \%$. Variabel benih tidak berpengaruh nyata terhadap peningkatan produksi jagung manis. Hal ini ditunjukan oleh nilai t-hit < t-tab yaitu 1,059 lebih kecil dari 2,300 maka keputusannya terima HO tolak $\mathrm{H} 1$ berarti bahwa penambahan pupuk urea tidak berpengaruh nyata terhadap peningkatan produksi jagung manis pada tingkat keyakinan 95\%. Untuk mengetahui pengaruh hubungan faktor produksi terhadap produksi jagung manis (variabel tidak bebas) secara bersama-sama dapat diuji dengan menggunakan Uji F statistik dengan menghitung terlebih dahulu besarnya variabel tidak bebas (dependent variabel) yang dapat diterangkan oleh variabel bebas (independent variabel) (Gujarati, 1978).

\section{Analisis Efisiensi Penggunaan Tenaga Kerja}

Tabel 3. Efisiensi Ekonomi Penggunaan Faktor Produksi Jagung Manis di Daerah Penelitian Musim Tanam 2013.

\begin{tabular}{lcccc}
\hline \multicolumn{1}{c}{ Uraian } & $\mathrm{Bi}$ & $\mathrm{Xi}$ & NPMxi & IExi \\
\hline Tenaga Kerja & 0,124 & 12,32953125 & 136755,864 & 2,73 \\
Benih & 0,751 & 20,359375 & 5015927,95 & 55,732 \\
Pupuk Kandang & 0,048 & 1103,125 & 591,6869 & 0,3944 \\
Pupuk Urea & 0,072 & 236,4063 & 4141,42 & 0,82825 \\
\hline
\end{tabular}

Dari Tabel 3 dapat dilihat bahwa nilai perbandingan $\mathrm{NPMx} x_{1} / \mathrm{Px}_{1}>1$ adalah sebesar 2,73 dengan demikian penggunaan faktor produksi tenaga kerja di daerah penelitian belum efisien. Hal ini berarti penggunaan tenaga kerja pada usahatani jagung manis di daerah penelitian perlu ditambah pemakaiannya guna mendapatkan produksi yang optimal dan keuntungan yang maksimum. Sedangkan nilai perbandingan $\mathrm{NPMx}_{2} / \mathrm{PMx}_{2}>1$ adalah sebesar 55,732 dengan demikian penggunaan faktor produksi benih belum efisien. Maka untuk mendapatkan 
yang optimum, penggunaan faktor produksi benih perlu ditambah pemakaiannya.Sementara dilihat dari nilai perbandingan $\mathrm{NPMx}_{3} / \mathrm{Px}_{3}<1$ adalah sebesar 0,3944 dengan demikian penggunaan pupuk kandang tidak efisien. Hal ini berarti penggunaan pupuk kandang pada usahatani jagung manis perlu dikurangi guna mendapatkan produksi yang optimal. Sementara untuk nilai perbandingan $\mathrm{NPMx}_{4} / \mathrm{Px}_{4}<1$ adalah sebesar 0,82825 artinya penggunaan pupuk urea didaerah penelitian tidak efisien. Hal ini berarti penggunaan faktor produksi pupuk urea pada usahatani jagung manis di daerah penelitian perlu dikurangi guna mendapatkan produksi optimal dan keuntungan maksimum. Hal ini berarti sesuai dengan teori (Soekartawi, 1994), yang menyatakan bahwa prinsip optimalisasi penggunaan faktor produksi pada prinsipnya adalah bagaimana menggunakan ataupun mengkombinasikan faktor produksi tersebut seefisien mungkin, namun dalam kehidupan sehari-hari kenyataan yang sebenarnya nilai produksi marginal tidak selalu sama dengan satu melainkan yang sering terjadi adalah suatu kondisi yang menunjukan evaluasi terhadap penggunaan berbagai faktor produksi selama proses produksi yang dinyatakan dengan efisien atau belum efisiennya penggunaan faktor produksi tersebut.

\section{Biaya Produksi pada Usahatani Jagung Manis}

Dalam usahatani jagung manis, petani mengeluarkan biaya dalam proses produksi. Biaya yang penggunaannya tidak habis dalam satu masa produksitunai yang dikeluarkan yaitu biaya yang habis terpakai dalam satu kali proses produksi, meliputi: biaya benih, pupuk, obatobatan dan upah tenaga kerja luar keluarga. Sedangkan biaya yang diperhitungkan adalah semua biaya yang tidak dikeluarkan oleh petani secara langsung tetapi diperhitungkan sebagai biaya, meliputi: biaya sewa lahan, penyusutan alat dan biaya tenaga kerja dalam keluarga (Hernanto, 1996). Dapat dilihat bahwa biaya rata-rata produksi usahatani jagung manis di daerah penelitian sebesar Rp.2723812.598 biaya rata-rata yang paling besar dikeluarkan secara tunai di daerah penelitian yaitu biaya benih, sebesar Rp,1.56503.5938 diikuti dengan biaya pupuk Rp.2.386.250 dan biaya benih sebesar Rp 1.811.250, biaya upah TKLK sebesar 2,5. Untuk biaya rata-rata yang diperhitungkan pada usahatani jagung manis biaya rata-rata yang terbesar yang dikeluarkan adalah penyusutan alat sebesar Rp. 21199.21875, diikuti biaya upah TKDK sebesar Rp. 9.82953125 dan biaya sewa lahan sebesar Rp. 691406.25 .

\section{Produksi Usahatani Jagung Manis}

Dalam suatu usaha pertanian, produksi diperoleh melalui proses yang sangat panjang dengan waktu yang cukup lama dan tergantung pada jenis komoditi yang diusahakan dengan demikian bahwa suatu fungsi dari suatu produksi yang dihasilkan merupakan cerminan dari interaksi antara satu input dengan input lainnya yang saling terkait satu sama lainnya selama prosese produksi berlangsung. Semakin banyak input yang digunakan maka produksi akan semakin tinggi atau bahkan semakin rendah (Daniel, 2004). Tanaman jagung manis di daerah penelitian dapat di panen umur 75-90 hari. Dari hasil penelitian 64 petani sampel diperoleh rata-rata produksi tiap petani adalah 5485,9375 kg sedangkan rata-rata produksi per hektarnya adalah 3967,2316 kg.

\section{Penerimaan Usahatani Jagung Manis}

Penerimaan merupakan salah satu komponen yang menentukan tingkat pendapatan. Penerimaan usahatani diperoleh melalui perkalian antara total produksi 
dengan harga jual per satuan produksi. Petani jagung manis di daerah Penelitian menghasilkan tongkol jagung manis. Untuk mengetahui komponen penerimaan pada usahatani jagung manis di daerah penelitian dapat dilihat pada tabel 4 .

Tabel 4. Rata-rata produksi, Harga dan Penerimaan pada Usahatani Jagung Manis di Daerah Penelitian Musim Tanam 2013

\begin{tabular}{cc}
\hline Uraian & Jumlah \\
\hline Produksi (Tongkol) & 5487.5 \\
Harga (Rp) & 2478 \\
Penerimaan (Rp) & 13508593.75 \\
\hline
\end{tabular}

Dari Tabel 4 diatas dapat dilihat bahwa di daerah penelitian produksi rata-rata 5487.5 (tongkol) dan harga jual rata-rata produksi jagung manis dalam bentuk tongkol sebesar Rp. 2478 sehingga penerimaan petani jagung manis di daerah penelitian sebesar Rp.13508593.75.

\section{Pendapatan Usahatani Jagung Manis}

Keberhasilan dari suatu usahatani dapat dilihat dari pendapatan bersih usahataninya. Pendapatan bersih usahatani berarti mengukur imbalan yang diperoleh petani dari penggunaan faktor-faktor produksi, yang digunakan. Pendapatan yang dimaksud dalam penelitian ini adalah pendapatan bersih yang diterima oleh petani dalam satu kali musim tanam. Besarnya pendapatan usahatani yang diperoleh petani di daerah penelitian dapat dilihat pada tabel 5 .

Tabel 5. Rata-rata pendapatan bersih dan nilai R/C usahatani jagung manis di daerah penelitian musim tanam 2013

\begin{tabular}{cc}
\hline Uraian & Jumlah \\
\hline Total Penerimaan (TR) & 13508593.75 \\
Totol Biaya (TC) & 2723812.598 \\
Pendapatan & 19121675.47 \\
R/C & 4.95 \\
\hline
\end{tabular}

dapat dilihat bahwa rata-rata pendapatan bersih petani di daerah penelitian adalah sebesar 19121675.47 per luas lahan 1.3828125 ha. Pendapatan di peroleh dari selisih total penerimaan dengan total biaya. Selanjutnya untuk melihat kelayakan usahatani jagung manis di daerah penelitian di gunakan kriteria investasi yaitu Revenue cost ratio $(R / C)$. Usahatani jagung manis di daerah penelitian cukup menguntungkan, hal ini terlihat dari $R / C$ sebesar 4,95. Hal ini menunjukan bahwa setiap rupiah yang di investasikan akan memberikan keuntungan sebesar Rp 4,95.

Penelitian yang dilakukan oleh Umbu Lando Paranggi (2011) yang berjudul Analisis Ekonomi Usahatani Jagung Manis bertujuan untuk mengetahui pengaruh produksi usahatani jagung manis di Kecamatan Kumpeh Ulu Kabupaten Muaro Jambi. Digunakan fungsi produksi dan diduga dengan menggunakan metode MLE dengan mengasumsikan CobbDouglas adalah bentuk fungsional fungsi produksi jagung di daerah penelitian. Hasil penelitian ini menunjukkan bahwa sebagian besar peubah yang diikutkan dalam model adalah signifikan dan mempunyai tanda sesuai harapan, kecuali peubah luas lahan dan tenaga kerja yang tidak signifikan. Penelitian ini juga menemukan bahwa petani mempunyai 
efisiensi teknik antara. Hasil penelitian ini juga menemukan bahwa lama pendidikan mempunyai tanda sesuai harapan dan nyata pada taraf 95 persen, sementara ukuran usahatani tidak meskipun mempunyai tanda positif. Lebih lanjut, faktor umur dan pengalaman petani mempunyai tanda negatif dan bukan merupakan faktor penting mempengaruhi tingkat efisiensi teknik yang diperoleh petani.

\section{KESIMPULAN}

Secara bersama-sama penggunaan faktor produksi tenaga kerja, benih, pupuk kandang, dan pupuk urea mempengaruhi produksi jagung manis, namun secara individual, faktor produksi benih, pupuk kandang dan pupuk urea yang berpengaruh nyata terhadap peningkatan produksi jagung manis, sedangkan tenaga kerja tidak berpengaruh nyata, karena penggunaan tenaga kerja dalam mengelola usahatani di daerah penelitina cenderung sama walaupun luas lahan yang diusahakan berbeda hal ini terjadi karena penggunaan lahan pada usahatani jagung manis relatif kecil. Tetapi keempat faktor produksi tersebut memiliki angka yang berpengaruh positif terhadap peningkatan produksi.

Penggunaan faktor produksi tenaga kerja dan benih di daerah penelitian tidak efisien lagi secara ekonomis. Hal ini berarti penggunaan faktor produksi tenaga kerja dan benih perlu dikurangi untuk mendapatkan produksi yang optimum. Sementara penggunaan faktor produksi pupuk kandang dan pupuk urea belum mencapai tingkat efisiensi secara ekonomis. Hal ini berarti penggunaan faktor produksi pupuk kandang dan pupuk urea perlu ditambah untuk mendapatkan keuntungan yang maksimum.

Pendapatan rata-rata yang diperoleh petani di daerah penelitian per musim tanam yaitu sebesar Rp. 19121675.47 dengan rata-rata luas lahan sebesar 1.3828 ha dan nilai R/C sebesar 4,95. Hal ini menunjukan bahwa usahatani jagung manis di daerah penelitian tergolong menguntungkan.

\section{UCAPAN TERIMA KASIH}

Terima kasih Kepala BP3K Kecamatan Kumpeh Ulu, Kepala Desa Kasang Lopak Alai, serta Dinas Pertanian Provinsi Jambi dan Badan Pusat Statistik Provinsi Jambi yang telah membantu dalam penelitian ini.

\section{DAFTAR PUSTAKA}

Badan Pusat Statistik. 2010. Muaro Jambi Dalam Angka 2011. Badan Pusat Statistik Provinsi Jambi.

Badan Pusat Statistik. 2011. Jambi Dalam Angka. BPS Provinsi Jambi.

Balai Penyuluh Pertanian Kecamatan Kumpeh Ulu. 2011. Laporan Tahunan Komoditi Jagung di Kecamatan Kumpeh Ulu. Muaro Jambi.

Daniel, M. 2004. Pengantar Ekonomi Pertanian. Bumi Aksara. Jakarta.

Gujarati, D. 1978. Ekonometrika Dasar. Erlangga. Jakarta.

Hernanto, F. 1996. IImu Usahatani. Penebar Swadaya. Jakarta.

Lando, Umbu Paranggi. 2011. Analisis Efisiensi Ekonomi Usahatani Jagung Manis di Kecamatan Kumpeh Ulu Kabupaten Muaro Jambi. Fakultas Pertanian. Universitas Jambi.

Nazir. 2005. Metode Penelitian. PT.Ghalia. Jakarta.

Soekartawi. 1994. Teori Ekonomi Produksi. PT. Rajawali Grafindo Persada. Jakarta. 